Damrau, F. (1962). Fournal of the American Geriatric Society, 10,

Drake, W. M. (1948). Fournal of Urology, 59, 650.

Feaver, B. D., Usher, M., and MacEwan, D. W. (1967). Fournal of the Canadian Association of Radiologists, 18, 442.

Flocks, R. H. (1963). In Urology, 2nd ed., vol. 2, edited by M. F. Campbell, p. 1158

Garrelts, B. von (1956). Acta Chirurgica Scandinavica, 112, 326

Garrelts, B. von (1957). Acta Chirurgica Scandinavica, 114, 197.

Griffiths, H. J. L., and Castro, J. E. (1969). Unpublished.

Holm, H. H. (1964). Acta Radiologica, Suppl. No. 231.

Kaufman, J. J. (1957). Fournal of Urology, 78, 97.
Rankin, J. T. (1967). British fournal of Urology, 39, 594.

Schwartz, O. (1920). Wiener Archiv für innere Medizin, 1, 455.

Scott, F. B., Cardus, D., Quesada, E. M., and Riles, T. (1967). Southern Medical fournal, 60, 948.

Smith, J. C. (1965). Lancet, 1, 90.

Smith, J. C. British Fournal of Urology, 38, 542 .

Thumann, R. C., jun. (1951). American fournal of Roentgenology, 65 , 593.

Vermooten, V., and Schweinsberg, M. (1964). Radiology, 182, 1010.

Wildbolz, E. (1958). Proceedings of the Royal Society of Medicine, 51, 1029.

\title{
Effects of a Cardio-selective Beta-adrenergic Blocker (I.C.I. 50172) at Exercise in Angina Pectoris
}

\author{
N.-H. ARESKOG, ${ }^{*}$ M.D. ; L. ADOLFSSON,* M.D.
}

\begin{abstract}
Summary : A cardio-selective beta-adrenergic blocking $\checkmark$ agent (I.C.I. 50172), which has been studied both in normal subjects and in patients with angina pectoris during and after a standardized work test, produced a significant increase in the exercise tolerance of the patients. These favourable effects are comparable with those of propranolol.
\end{abstract}

One patient with severe bronchial asthma and coronary insufficiency treated with I.C.I. 50172 improved and his respiratory function was not impaired.

\section{Introduction}

The qualitatively new beta-adrenergic blocking drug I.C.I. 50172 (Eraldin; 4-(2-hydroxy-3-isopropylaminopropoxy) acetanilide) acts predominantly on cardiac beta-receptors. Doses which block cardiac beta-receptors have no influence on the beta-receptors of the bronchial and vascular smooth muscle

\footnotetext{
* Physician, Department of Clinical Physiology, Region Hospital,
} Linkoping, Sweden.
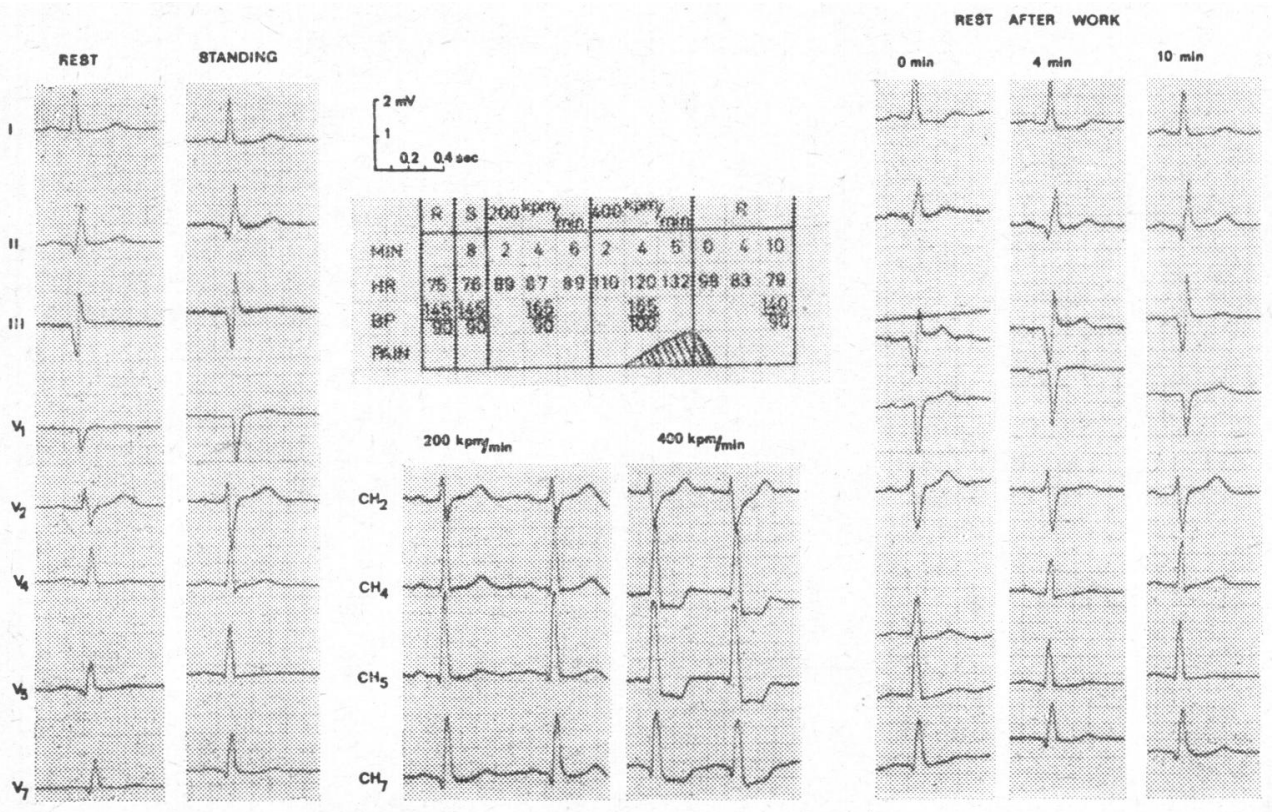

Test procedure.
(Dunlop and Shanks, 1968 ; Barrett et al., 1968 ; Gibson and Sowton, 1968 ; Macdonald and McNeill, 1968). Unlike propranolol it has intrinsic sympathomimetic activity but no local anaesthetic (quinidine-like) action (Dunlop and Shanks, 1968). It has a far longer half-life (10 hours) than propranolol (two hours) (Fitzgerald and Scales, 1968). Thus this new beta-adrenergic blocking agent is interesting from many clinical points of view. This report concerns its effects during and after standardized work tests in normal and anginal subjects. The effects in angina are compared with those obtained in our earlier study with propranolol (Areskog and Adolfsson, 1967).

\section{Materials and Methods}

To determine the equipotent doses of propranolol and I.C.I. 50172 a pilot study was performed in normal subjects. Five men and five women (mean age 39 and 26 years, mean weight 72 and $57 \mathrm{~kg}$., respectively) performed a standardized work test on a bicycle ergometer (Sjöstrand, 1947) before and after the administration of propranolol ( $5 \mathrm{mg}$. intravenously) and I.C.I. 50172 (20 mg. intravenously). The injection rate was 1 and $4 \mathrm{mg}$. per minure, respectively. One test was carried out daily under identical conditions.

Of the group of 19 patients (14 men and 5 women, mean age 56 years, range 38-72 years; mean weight $71 \mathrm{~kg}$., range $50-103 \mathrm{~kg}$. with angina, or coronary insufficiency, or both, showing typical E.C.G. alterations at rest or on a standardized submaximal work test, six had slight to moderate hypertension, and one E.C.G. signs or earlier myocardial infarction. After an interval of some days a further work test was performed 20 minutes after the administration of I.C.I. $50172(20$ mg. intravenously per five-minute run). Six of the patients performed a funther exercise test after at least two weeks' treatment by mouth with I.C.I. $50172(100 \mathrm{mg}$. b.d.). The time, meal-load conditions, and timing of the test were 
identical with those in the control test. The exercise tests, however, were stopped after symptoms of anginal pain, or a typical E.C.G. reaction of coronary insufficiency, or both, had appeared. These patients were then asked to break the following test at the point where the same degree of pain recurred, provided the E.C.G. reaction did not contraindicate this. S-T depression was defined as $1 \mathrm{~mm}$. depression compared with the E.C.G. at rest, with a pattern typical of coronary insufficiency (Areskog and Hallén, 1964 ; Areskog and Adolfsson, 1967). The following variables were recorded:

(1) During Work.-Total work performed, work time, and heart rate at $(a)$ the appearance of angina, $(b)$ at the appearance of S-T depression, and $(c)$ at the end of the test. The respiratory rate and the systolic blood pressure (cuff method) were also recorded.

(2) After Work.-Disappearance times of angina and E.C.G. changes were recorded. The degree, type, and time course of the E.C.G. changes during and after work were noted.

The test procedure is schematically illustrated in the Chart.

\section{Results}

Normal Volunteers.-In both sexes the percentage reduction in exercise tachycardia was similar with both drugs, though the response of the women was somewhat greater than that of the men (Table I). This may be due to the proportionately higher dose per $\mathrm{kg}$. body weight in the women. The reduction in the systolic blood pressure, which occurred generally during exercise, was greater on submaximal than maximal load but possibly less in the women than in the men. On average the reduction in the men was $10 \%$ with I.C.I. 50172 and $14 \%$ with propranolol on submaximal load. The figures for the women were $2 \%$ and $6 \%$, respectively. Nevertheless, the variations between persons were more pronounced than for the changes in heart rate. The results suggested that an intravenous dose of $20 \mathrm{mg}$. of I.C.I. 50172 was equivalent to $5 \mathrm{mg}$. of propranolol.

TABLE I.-Percentage Reduction of Heart Rate at Rest and During Work After Propranolol and I.C.I. 50172 in Normals

\begin{tabular}{|c|c|}
\hline $\begin{array}{l}\text { Rest: } 10 \mathrm{~min} . \\
\text { after injection }\end{array}$ & $\left\{\begin{array}{l}\text { Mean } \\
\text { S.D. } \\
\mathrm{n}\end{array}\right.$ \\
\hline $\begin{array}{l}\text { Exercise: } \\
\quad 600 \mathrm{kp} . \mathrm{m} . / \mathrm{min} .\end{array}$ & $\begin{array}{l}\text { Mean } \\
\text { S.D. } \\
\text { n }\end{array}$ \\
\hline $900 \mathrm{kp} . \mathrm{m} . / \mathrm{min}$ & $\begin{array}{l}\text { S.D. } \\
\text { n }\end{array}$ \\
\hline $1,200 \mathrm{kp} . \mathrm{m} . / \mathrm{min}$ & $\begin{array}{l}\text { S.D. } \\
\text { n }\end{array}$ \\
\hline
\end{tabular}

$$
\text { Men }
$$

\begin{tabular}{|c|c|}
\hline $\begin{array}{l}\text { Rest: } 10 \mathrm{~min} \text {. after } \\
\text { injection }\end{array}$ & $\begin{array}{l}\text { Mean } \\
\text { S.D. }\end{array}$ \\
\hline $\begin{array}{l}\text { Exercise: } \\
\quad 400 \mathrm{kp} . \mathrm{m} . / \mathrm{min} .\end{array}$ & \\
\hline $600 \mathrm{kp} . \mathrm{m} . / \mathrm{min}$. & $\begin{array}{l}\text { S.D. } \\
\text { n. }\end{array}$ \\
\hline $800 \mathrm{kp} . \mathrm{m} . / \mathrm{min}$. & $\begin{array}{l}\text { S.D. } \\
\mathrm{n}\end{array}$ \\
\hline
\end{tabular}

$8 \cdot 9$
$13 \cdot 4$
5
$17 \cdot 6$
$3 \cdot 6$
5
$18 \cdot 4$
$5 \cdot 1$
$5 \cdot 6$
$18 \cdot 6$
$3 \cdot 6$
3

\begin{tabular}{c|c} 
& \\
$13 \cdot 1$ & $9 \cdot 4$ \\
$5 \cdot 2$ & $6 \cdot 9$ \\
5 & 5 \\
$13 \cdot 9$ & $13 \cdot 7$ \\
$3 \cdot 2$ & $3 \cdot 0$ \\
5 & $5 \cdot 3$ \\
$14 \cdot 3$ & $16 \cdot 3$ \\
$5 \cdot 5$ & $5 \cdot 7$ \\
5 & 5 \\
$13 \cdot 8$ & $14 \cdot 4$ \\
$4 \cdot 1$ & $2 \cdot 4$ \\
4 & 4
\end{tabular}

Anginal Patients.-The effects on exercise tolerance of I.C.I. $50172(20 \mathrm{mg}$.) given intravenously in 19 anginal patients and by mouth in six patients are summarized in Table II.

Intravenous Results.-The percentage changes, which are summarized in Table III, were statistically significant at the $1 \%$ level, except the effects of I.C.I. 50172 on " disappearance times," contrary to propranolol. These results indicate that I.C.I. 50172 increases acute exercise tolerance in terms of both the symptoms and the signs of coronary insufficiency.

Oral Results.-Repetition of the exercise test in six of the above patients receiving I.C.I. 50172 (200 mg. daily) showed
TABLE II.-Results of Standardized Work Test in 19 Patients with Angina Pectoris

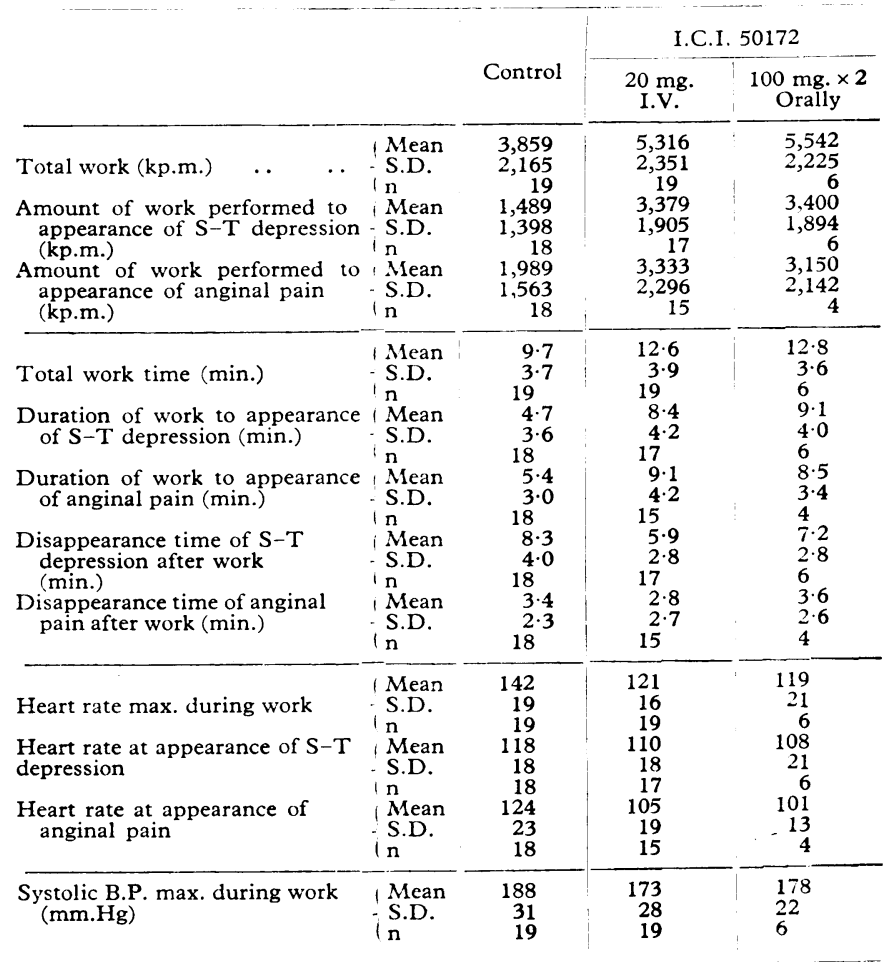

TABLE III.-Effects of Propranolol and I.C.I. 50172 in Two Studies with Angina Patients. The Figures Represent the Percentage Change After Beta-Adrenergic Blockade Compared with a Control
Test

\begin{tabular}{|c|c|c|c|c|}
\hline & $\begin{array}{l}\text { Propranolol } \\
(5 \mathrm{mg} \text {. I.V. })\end{array}$ & $\mathrm{n}$ & $\begin{array}{l}\text { I.C.I. } 50172 \\
(20 \mathrm{mg} . \mathrm{I} . \mathrm{V})\end{array}$ & $\mathrm{n}$ \\
\hline al work & +25 & 33 & +38 & 19 \\
\hline ression & +90 & 33 & +127 & 17 \\
\hline $\begin{array}{l}\text { art rate maximum during work } \\
\text { eart rate to appearance of anginal pain }\end{array}$ & $\begin{array}{l}-17 \\
-16\end{array}$ & $\begin{array}{l}33 \\
21\end{array}$ & $\begin{array}{l}-15 \\
-15\end{array}$ & $\begin{array}{l}19 \\
15\end{array}$ \\
\hline $\begin{array}{l}\text { eart rate to a } \\
\text { otal work tin }\end{array}$ & +24 & 33 & +30 & 19 \\
\hline isappearance ti & $\begin{array}{l}-37 \\
-51\end{array}$ & 33 & $\begin{array}{l}-15 \\
-29\end{array}$ & 17 \\
\hline $\begin{array}{l}\text { isappearance time } \\
\text { vstolic B.P. maxim }\end{array}$ & & 31 & -8 & 19 \\
\hline
\end{tabular}

quantitatively similar results. Of the 19 patients only one did not experience pain in the control test, but had E.C.G. signs of myocardial ischaemia, while 3 did not develop pain after receiving I.C.I. 50172. On the other hand, another patient developed pain but no E.C.G. alterations during the control test, while a further patient had his E.C.G. response abolished by I.C.I. 50172. In these patients exercise was limited by fatigue.

Side-effects and Other Observations.-No complications or important side-effects were observed after intravenous treatment. The normal subjects and some of the patients complained of tiredness in the legs, but this was less severe than after propranolol. One patient receiving I.C.I. 50172 by mouth had a tendency to insomnia the first week after it was started. No change in the haematological status or in routine liver and renal function tests was seen in the patients taking the drugs by mouth (list tests performed). One patient developed severe incapacitating pain in her hip during propranolol treatment. This disappeared, however, when I.C.I. 50172 replaced propranolol. Similarly, one patient with both angina and bronchial asthma improved subjectively and has spontaneously given up taking his usual drugs for asthma. Three out of four patients who were formerly receiving propranolol treatment preferred I.C.I. 50172 .

\section{Discussion}

These favourable effects of I.C.I. 50172 in angina pectoris are comparable with those reported earlier in a similar study 
of the effects of propranolol (5 mg. intravenously) (Table III) (Areskog and Adolfsson, 1967). Only four of the patients took part in both studies. In the propranolol study 8 of the 33 patients did not get anginal pain in spite of an E.C.G. pattern typical of coronary insufficiency, whereas in this study 3 out of 19 patients had a similar response. Thus propranolol in many cases produced a change in the usually constant time relationship between pain and E.C.G. "threshold" during work (Areskog and Hallén, 1964). This change, which implies a retardation of the appearance time of the pain compared with the appearance time of the $\mathrm{S}-\mathrm{T}$ depression was seen in a few cases also after I.C.I. 50172. It is still not clear whether there is a real difference between the two drugs in this respect.

Propranolol seems to give a more rapid relief of both subjective and objective signs of coronary insufficiency after exercise. This might be due to its lack of intrinsic sympathomimetic activity in comparison with that of I.C.I. 50172. Since I.C.I. 50172 produces an overall improvement of the anginal pain to about the same degree as propranolol, the local anaesthetic action of the latter does not seem to be an important factor in relieving angina, as has been suggested (Levy and Richards, 1965 ; Grandjean, 1967). The improvement in the condition of the patient with coronary insufficiency and bronchial asthma is a remarkable result, and may have been, in the case of asthma, due to the intrinsic sympathomimetic activity of I.C.I. 50172. Macdonald and McNeill (1968) found a decrease in the airway resistance in 2 out of 10 patients, but an average rise of $22.6 \%$ after $15 \mathrm{mg}$. of I.C.I. 50172 intravenously. Because of its cardioselectivity this drug may be given to patients with obstructive lung disease in contradistinction to propranolol. Theoretically, owing to its intrinsic sympathomimetic activity I.C.I. 50172 might be a less dangerous drug than propranolol to give to patients with incipient cardiac insufficiency. We always recommend the combination of digitalization and beta-blockade in these cases.

The favourable effect of I.C.I. 50172 on coronary insufficiency cannot be fully explained by the reduction in heart rate, since the angina appears at a much lower heart rate after I.C.I. 50172. Dwyer et al. (1967) found that the effect of propranolol in angina derives mainly from suppression of contractility (left ventricular first derivative) and to a less extent from the negative chronotropic action. With the use of the formula

$$
\text { ventricular work }=Q R \frac{\mathrm{mv}^{2}}{2}
$$

where $\mathrm{Q}=$ stroke volume, $\mathrm{R}=$ the mean arterial pressure (metres $\mathrm{H}_{2} \mathrm{O}$ ), $\mathrm{m}=$ the mass of ejected blood, and $\mathrm{v}=$ velocity, I.C.I. 50172 in the dose we used decreases the work by reducing not the stroke volume (and thereby not the mass of ejected blood) but the velocity and the mean arterial pressure (Sowton et al., 1968), which in turn lowers oxygen consumption. The product of mean systolic pressure times duration of systole times heart rate (tension time index)-which corresponds well to myocardial oxygen consumption-would suggest that the reduction in oxygen consumption is about $15 \%$, by the use of our own data and those of Sowton et al. (1968). Since total work and especially work at the appearance of S-T depression are relatively much more increased, other factors must be concerned. The reduction of the myocardial contractility prolongs systole (Apthorp et al., 1964) and reduces extravascular resistance to coronary flow, which may also improve the coronary perfusion during work (Gregg, 1964 ; Moir and DeBra, 1967). In the case of propranolol experimental data also support the possibility of improved oxygen utilization at the cellular level with reduced production of lactate $(\AA$. Hjalmarson, personal communication; Wolfson et al., 1966). Whether these findings apply to I.C.I. 50172 is still unknown.

Apthorp, G. H., Chamberlain, D. A., and Hayward, G. W. (1964). British Heart fournal, 26, 218.

Areskog, N.-H., and Adolfsson, L. (1967). Läkartidningen, 64, 83. Areskog, N.-H., and Hallen, A. (1964). Acta Chirurgica Scandinavica.

Suppl. No. 323, p. 70. Smith L., C. (1968). Naunyn-Schmiedeberg's Archiv für Experimentelle Pathologie und Pharmakodynamie, 259, 152.

Dunlop, D., and Shanks, R. G. (1968). British fournal of Pharmaco$\log y, 32,201$.

Dwyer, E. M., Wiener, L., and Cox, J. W. (1967). Circulation, 36, Suppl. No. 2, p. 99.

Fitzgerald, J. D., and Scales, B. (1968). Internationale Zeitschrift für klinische Pharmacologie, Therapie und Toxikologie, 1, 467.

Gibson, D., and Sowton, E. (1968). British Medical fournal, 1, 213. Grandiean, T. (1967). Schweizerische Medizinische Wochenschrift, 97, 1559 .

Gregg, D. E. (1964). In Oxygen in the Animal Organism, edited by F. Dickens and E. Neil, p. 325. Oxford, Pergamon Press.

Levy, J. V., and Richards, V. (1965). Foumal of Pharmacology and Experimental Therapeutics, 150, 361 .

Macdonald, A. G., and McNeil, R. S. (1968). British fournal of Anaesthesia, 40, 508.

Moir, T. W., and DeBra, D. W. (1967). Circulation Research, 21, 65. Sjöstrand, T. (1947). Acta Medica Scandinavica, Suppl. No. 196, p. 687.

Sowton, E., Balcon, R., Cross, D., and Frick, H. (1968). British Medical fournal, 1, 215.

Wolfson, S., Sullivan, J. M., and Gorlin, R. (1966). Circulation, 34, Suppl. No. 3, p. 241 .

\section{Introduction}

Defects of the central nervous system, including microcephaly, spasticity, and mental retardation, are the most serious mani- festations of congenital cytomegalic inclusion disease, though they may not appear until the second year of life (Weller and Hanshaw, 1962; Medearis, 1964; Hanshaw, 1966). Clinical features commonly appearing in the neonatal period are hepatomegaly, splenomegaly, jaundice, and haemolytic disease. Though asymptomatic infection with cytomegalo-

* Senior House Officer, Lewisham Hospital, London S.E.13.

† Virus Reference Laboratory, Colindale Public Health Laboratory, London N.W.9. 